\title{
The Impact of New Products on Ethical Beliefs
}

\author{
Eva Vivalt* \\ The Australian National University \\ Bobbie Macdonald ${ }^{\dagger}$ \\ Stanford University
}

November 8, 2017

\begin{abstract}
We test whether the availability of consumer goods affects ethical beliefs. Several new firms are developing "clean" animal products: lab-grown meat, egg, and dairy products that do not rely on traditional animal agriculture. Standard models of cognitive dissonance would predict that the mere availability of such a product would lead consumers to put more moral weight on the environment and farm animals. We do not initially observe this and in fact find that information about clean meat may even negatively affect beliefs. A second experiment in which we use priming to randomly manipulate how positively respondents view the product explains the surprising result: due to concerns about the "unnaturalness" of the product, many do not find it an acceptable substitute, however, those who perceive the product positively do change their ethical beliefs.
\end{abstract}

*E-mail: eva.vivalt@anu.edu.au.

${ }^{\dagger}$ E-mail: bmacdon@stanford.edu. 


\section{Introduction}

Products can be linked to ethical issues in their production. For example, many people demand "fair trade" coffee or carbon offsets for flying. Often, the "best" ethical choice is inconvenient for consumers, whether because of cost, availability, or simply because it requires a change in purchasing habits. Standard models of cognitive dissonance (e.g. Rabin, 1994) imply that consumers may resolve this dilemma by selecting the "bad" ethical option and then downplay or willfully ignore the ethical implications of their purchase. As a result, where ethical products are especially expensive, inconvenient, or low quality, consumers will be especially likely to rationalize their "bad" ethical purchase by constructing a set of beliefs that justifies their decision.

In this study, we examine whether improving the quality of an ethical option causes individuals to change their moral beliefs. Specifically, we conduct an experiment in which 1,800 respondents are randomized into receiving information about a new high quality meat substitute ("clean" or "cultured" meat, i.e. bio-identical meat grown in a lab), another meat substitute which is described in identical terms but is framed as a vegetarian product, or no information about new meat substitute products at all. Conventional animal agriculture causes more pollution than clean meat; causes animal suffering; and is associated with a growing incidence of antibiotic resistance (Aarestrup, 2005; Vieira et al., 2011; Tuomisto and Teixeira de Mattos, 2011; Tuomisto and Roy, 2012; Mattick et al., 2015). To the extent to which clean meat may represent a better substitute than vegetarian products, learning about clean meat could plausibly cause individuals to place more moral weight on the environment or on animals.

This topic has important practical implications. If the beliefs of consumers are a function of the quality or convenience of ethical options available, then improving these ethical options can produce a virtuous cycle of ethical consumption. In contrast, if consumers' ethical beliefs do not shift quickly with the introduction of improved ethical options, producers of ethical goods will need to find other strategies for nudging consumers into more ethical 
purchasing habits.

Contrary to what we expected to find in the first experiment, providing subjects with information about clean meat did not lead them to take a more negative view of conventional methods of animal agriculture (i.e. concentrated animal feeding operations, also known as factory farming) or place more weight on the environment or animal suffering. In fact, those told about new products - both clean meat and a vegetarian substitute, but especially clean meat - were less likely to change their beliefs than those who were not told about new products.

One possible explanation of these results is that other features of meat may have become more salient to those who were told about new products and consequently they were in less of an ethical mindset when participating in the study. We therefore conducted a second experiment in which we explicitly varied whether information was presented in an ethical framing, but this framing did not significantly alter our results.

Instead, we found support for an alternative hypothesis: that presently too many consumers find clean meat unappealing. First, we observed that those who responded more positively to either the clean meat or vegetarian product description were more likely to change their beliefs. We also observed a broad range of reactions to clean meat products, with some participants finding them "disgusting" or "unnatural" and some very excited about the new product. It still remained possible, however, that some other factor was causing this correlation. For example, perhaps those who react more positively to new products tend to change all their views more often, including their ethical views.

To causally attribute the differences in belief changes to how individuals perceived the product, we leveraged random variation in information provided in the second experiment. In this experiment, focusing on information treatments to combat the naturalistic heuristic, respondents were randomly primed to think of the "unnaturalness" of the product and/or provided one of several arguments to mitigate this concern. Since one of these treatments turned out to be a strong instrument for how positively subjects perceived clean meat, we could leverage it to determine whether the observed relationship between having a positive 
perception of clean meat and changing one's ethical beliefs was causal.

In the next section, we describe the exciting product at the centre of the study.

\section{Clean Meat: A New Technology on the Horizon}

Artificially grown meat - also known as clean meat or cultured meat - has attracted great media attention and public excitement (e.g. Ferdman, 2015; Stone, 2016). While not yet commercially available anywhere in the world, clean meat products are expected to be released to US consumers in the next 3-5 years, with some firms promising a commercially viable product in 2018 (Addady, 2016; Garfield, 2017). Crucially, clean meat products are meat from the actual tissue cells of animals, rather than plant-based sources that are used in other kinds of meat substitutes (e.g. tofu, tempeh). As a result, clean meat products will be marketed to consumers as a closer substitute to conventional meat products in terms of nutrition and taste compared to existing meat substitutes. The availability of clean meat products could thus reduce the perceived "cost" (including non-monetary costs) of avoiding conventional animal products. While clean meat is still relatively expensive to produce, it has recently fallen from $\$ 325,000$ per lb to $\$ 11.36$ per lb (Wang, 2017).

Clean meat has the potential to directly reduce the environmental footprint and animal suffering caused by conventional methods of producing meat, eggs, and dairy products. Animal agriculture has been estimated to cause 18-51\% of greenhouse gas emissions (Goodland and Anhang, 2009; FAO, 2006). Shifting to clean meat products could drastically reduce such emissions. Clean meat requires $99 \%$ less greenhouse gas emissions, $96 \%$ less water and 99\% less land than conventionally-produced meat (Tuomisto and Teixeira de Mattos, 2011; Tuomisto and Roy, 2012; Mattick et al., 2015). Further, as clean meat production does not require farm animals, ${ }^{1}$ farm animal suffering caused by overcrowding, debeaking, and the routine practice of surgical procedures without anaesthetic, among other causes, would be

\footnotetext{
${ }^{1}$ Currently, some starter serums used in production are derived from animals, however, the same serum can be re-used without additional animals being harmed. This serum thus can be thought of as similar to the inputs to many vaccines which were originally developed using animal cells. For example, the flu vaccine Flucelvax uses a cell culture derived from a cocker spaniel in 1958 (Ledford, 2012).
} 
reduced. ${ }^{2}$

However, clean meat products also could have additional indirect effects on the environment and animal welfare. In particular, if these products help to shift people's ethical beliefs about the environment or animals or otherwise lead them to attach more importance to environmental or animal welfare-related outcomes, they may take other actions that reflect their changed beliefs. For example, they may donate more money to non-profits that fight for farm animals to be covered by animal welfare laws, or they may be more likely to vote for environmental measures.

While we focus on the example of animal products in this study, the same cognitive mechanisms may be important in other settings. For example, people are often faced with a decision about whether to take a somewhat costly private action for a benefit for others, such as when there is some public good that one could affect through the externalities of one's actions. It is possible that reducing the cost of taking the socially optimal action not only directly increases the chances that action is taken, but also increases these chances indirectly by changing the individuals' beliefs about the morality of taking such an action. If the personal costs one faces in taking the socially optimal action are heterogeneous over time, changing one's ethical beliefs in a time when the socially optimal action has low cost could lock one in to taking the socially optimal action in the future, even in time periods in which the personal costs to taking the socially optimal action are higher.

We focus on clean meat and meat substitutes rather than some other domain of consumer choice (e.g. "fair trade" coffee) because vegetarianism is unambiguously associated with morality for many people and the personal costs of going vegetarian (monetary or otherwise) are a major barrier. For example, a recent Gallup poll found that only $3 \%$ of people stated that they do not believe animals require much protection from harm and exploitation because they are "just animals" (Riffkin, 2015). We take this as evidence that more people would avoid conventional animal products if a better substitute were available.

\footnotetext{
${ }^{2}$ It should be noted that animal welfare laws do not apply to farm animals in the U.S. (Animal Legal Defense Fund, 2017).
} 


\section{Methods}

\section{Study 1}

We recruited a total of 1,800 participants from Amazon's Mechanical Turk (MTurk) to participate in a two-wave survey. We restricted participation to US-based individuals, since clean meat products are expected to first be released in the United States and the United States is the world's top consumer of meat products (OECD, 2017). ${ }^{3}$

All subjects completed a baseline survey measuring demographic characteristics, current eating habits, attitudes towards meat products and substitutes, and other relevant variables. Participants were then randomly divided into several treatment arms. One set of subjects was exposed to information about clean meat alongside a persuasive message about the health, environmental, or ethical advantages of reducing consumption of conventional animal products. Another set was instead told about a new "animal-free" meat substitute with the same qualities, but they were not explicitly told that it was a clean meat product and they were told about the product in the context of vegetarian substitutes. ${ }^{4}$ Since clean meat products are new and not many people know about them, respondents not explicitly told about them would be expected to infer the product was a standard vegetarian product. A third set of respondents was provided the same information without mention of a new product. The three "product" treatment arms (clean meat, vegetarian substitute, no new product) were crossed with the three "message" treatment arms (health, environmental, ethical) with 200 subjects in each cell, for a total of 1,800 subjects.

Participants were then asked to watch a 90-second video about factory farming which provided more information about various ways in which it can harm farm animals. We then elicited a second round of ethical beliefs, asked some questions about expected future consumption, and asked if subjects would like more information about vegetarian products or, if they received information about a new product, if they would like to know when the

\footnotetext{
${ }^{3}$ We further required a HIT Approval Rate (\%) for all Requesters' HITs greater than or equal to 95 and Number of HITs Approved greater than or equal to 50.

${ }^{4}$ An appendix provides the exact wording used in each treatment arm.
} 
product that was described became available in their area.

One month later, a follow-up survey was conducted. Respondents were notified that the survey was available by a series of 3 e-mails, and $84 \%$ of those invited to take the survey completed it. The follow-up survey was intended to allow us both to track outcomes over time and to reduce the risk of social desirability bias. Respondents were again asked questions about their current consumption of animal products and about their ethical beliefs.

\section{Study 2}

Due to the surprising results, we conducted another experiment in which we made two main changes to the protocol. First, we were concerned that some people might be turned off by the description of the clean meat product. Thus, in the second iteration we referred to the product as "clean" meat, rather than "cultured" meat as in Study 1, as research by industry groups suggests people have a more favourable response to the product when described this way. Second, we wondered if individuals in the vegetarian substitute arm might be more likely to exhibit more change than those in the clean meat arm due to social desirability bias or due to ethical issues having more salience, since many people know vegetarians who avoid meat for ethical reasons. To mitigate this concern, we randomly assigned individuals to receive information in one of three framings: an "ethical" framing, a "process" framing, or a "neutral" framing. In the ethical framing, we asked respondents to consider whether they knew anyone who was vegetarian for ethical reasons and asked them to reflect on that; those receiving the process framing were the only ones who were still provided additional details about the process of creating clean meat cut for the other groups; the neutral framing group received neither the ethical questions nor the process description. If a framing or salience explanation were driving results, we might expect to observe differences between these treatment arms.

This experiment was embedded in another study on the naturalistic heuristic which considered how alternative messages could help to overcome a bias against the "unnatural" (Macdonald and Vivalt, 2017). We obtained 4,000 responses on MTurk, but due to the 
focus of this study, 3,200 of these were in the clean meat treatment arm, with only 400 receiving the vegetarian substitute treatment and another 400 receiving no new product information.

Respondents first answered questions about their ethical beliefs, the material beliefs they held about the harms caused to animals or the environment through conventional animal agriculture, and the personal weights they placed on these harms. They were then exposed to a new product treatment arm (or no new product), as before. They also saw the same video and were again asked questions about their beliefs.

Approximately 1 week later, those who had been assigned to one of the clean meat treatment arms were contacted to participate in a follow-up survey that primed half the subjects with negative social information about clean meat focusing on its "unnaturalness" and provided additional information countering the naturalistic heuristic. In particular, participants assigned to receive negative social information were shown five short quotes from previous respondents expressing negative sentiments about clean meat (e.g. "This seems very unnatural. I don't feel comfortable about this.", "Artificial meat sounds disgusting"). Participants who were not assigned to receive negative social information were shown nothing instead. For the messages countering the naturalistic heuristic, participants were asked to read an article of approximately 150-200 words, containing three images that helped to convey the main message. Participants were cross-randomized into receiving one of four messages: a placebo message, a debunking unnatural appeal, an embrace unnatural appeal, and a descriptive norm appeal. These appeals are described elsewhere (Macdonald and Vivalt, 2017).

The alternative appeals to overcome the naturalistic heuristic could have been used as an instrument for the perceived quality of the substitute, but unfortunately these strategies did not make a big enough difference to be a strong instrument. What was a strong instrument for how positively subjects viewed clean meat was simply whether they had been primed with negative social information highlighting the "unnaturalness" of the product $(\mathrm{F}=24.32)$. We will thus use this as a lever to consider the relationship between new products and 
changes in ethical beliefs.

Both studies were pre-registered with the American Economic Association (AEA) Randomized Controlled Trial (RCT) registry and pre-analysis plans posted at the Open Science Framework (OSF).

\section{Results}

Whether the hypothesized effects of clean meat are realized theoretically depends on the degree to which clean meat is indeed seen as a good substitute to conventional meat products. A potential complication is that some individuals may be subject to the "naturalistic heuristic", believing that meat that is not produced "naturally" is disgusting or unhealthy. Early studies of consumer demand for clean meat (Macfarlane, 2016; Verbeke, Sans and Van Loo, 2014; Wilks and Phillips, 2017) suggest that a large share or even sometimes the majority of consumers have a negative reaction to clean meat. Thus, rather than model changes in ethical beliefs as being a result of clean meat per se, we consider whether changes in ethical beliefs are mediated by how positively one responds to the new product, whether it is a clean meat product or a vegetarian meat substitute, and how much easier one believes it will be to reduce one's conventional meat consumption in the presence of such products.

We find that, indeed, there was more dispersion of reactions to clean meat than there was to the vegetarian substitute, with a greater number of subjects reporting either very negative or very positive reactions to clean meat (Figure 1a); a greater number of subjects in the clean meat treatments reporting it would be "very easy" or "very difficult" to reduce consumption of conventional meat products (Figure 1b); and a greater number of people in the clean meat treatment arms reporting concerns that the new product seemed "unnatural" or "unhealthy" (Figure 1c).

In Study 1, the description of the new product had no - or negative - effects on stated ethical beliefs (Table 1$).^{5}$

\footnotetext{
${ }^{5}$ Specifically, subjects were asked "Some people say that eating vegetarian food is morally preferable to eating conventional food products. What do you think? (Strongly agree, Agree, Somewhat agree, Neither agree nor disagree, Somewhat disagree, Disagree, Strongly disagree)". It should be noted that this question
} 
Figure 1: Dispersion of Attitudes towards Clean Meat
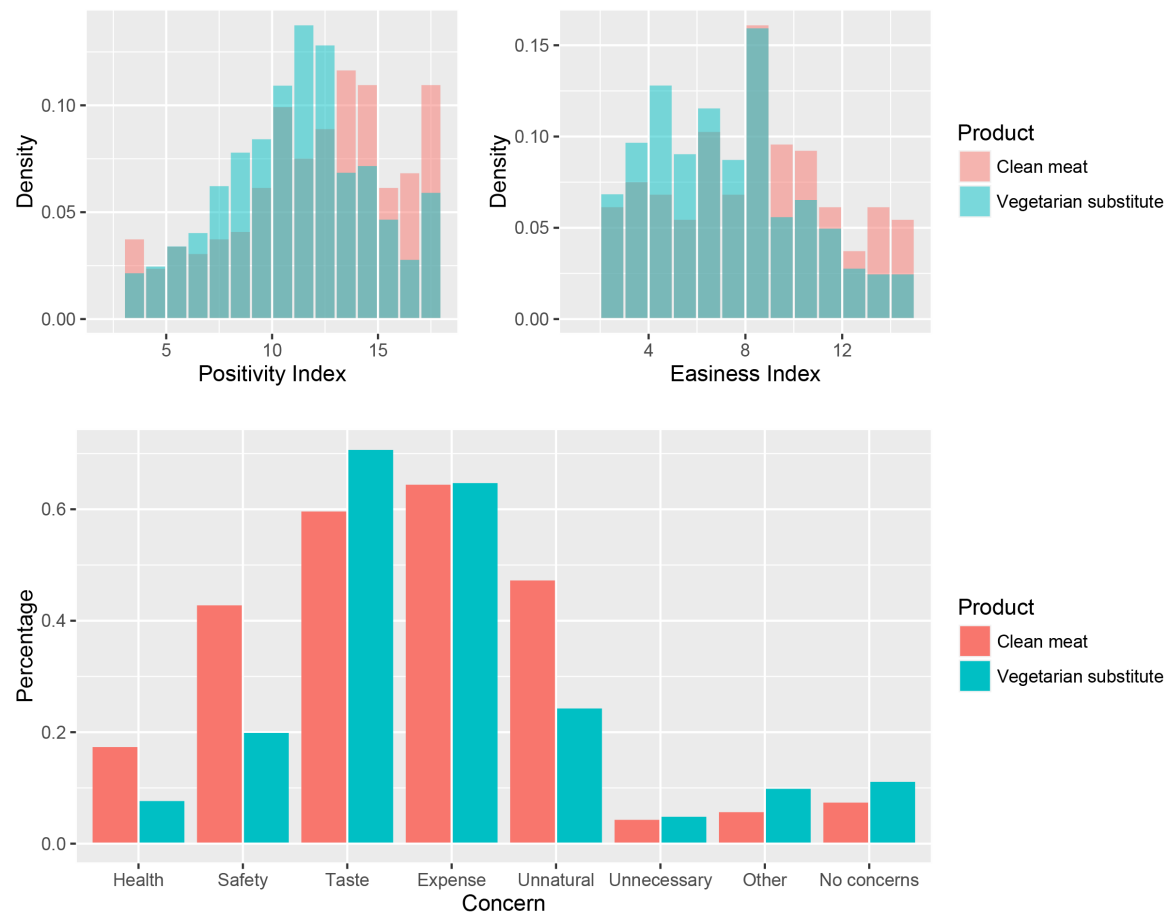

Table 1: Regression of Change in Beliefs and Donations on Treatments

\begin{tabular}{lcccccc}
\hline & $\begin{array}{c}(1) \\
\text { Morally } \\
\text { preferable }\end{array}$ & $\begin{array}{c}(2) \\
\text { Morally } \\
\text { preferable }\end{array}$ & $\begin{array}{c}(3) \\
\text { Morally } \\
\text { preferable }\end{array}$ & $\begin{array}{c}(4) \\
\text { Donation }\end{array}$ & $\begin{array}{c}(5) \\
\text { Donation }\end{array}$ & $\begin{array}{c}(6) \\
\text { Donation }\end{array}$ \\
\hline Clean meat & $-0.175^{*}$ & & & 0.249 & & \\
Vegetarian & $(0.09)$ & & & $(0.28)$ & & \\
substitute & 0.061 & & & -0.030 & & \\
Positivity index & $(0.09)$ & & & $(0.27)$ & & \\
& & $0.090^{* * *}$ & & & $0.242^{* * *}$ & \\
Easiness index & & $(0.01)$ & & & $(0.04)$ & \\
& & & $0.077^{* * *}$ & & & $0.269^{* * *}$ \\
Baseline value & $-0.389^{* * *}$ & $-0.451^{* * *}$ & $-0.451^{* * *}$ & & & $(0.03)$ \\
& $(0.02)$ & $(0.03)$ & $(0.03)$ & & & \\
Baseline meat & -0.005 & -0.003 & -0.004 & $-0.025^{* * *}$ & $-0.027^{* *}$ & $-0.019^{* *}$ \\
consumption & $(0.00)$ & $(0.00)$ & $(0.00)$ & $(0.01)$ & $(0.01)$ & $(0.01)$ \\
Constant & $2.941^{* * *}$ & $2.076^{* * *}$ & $2.579^{* * *}$ & $6.621^{* * *}$ & $4.035^{* * *}$ & $4.749^{* * *}$ \\
& $(0.12)$ & $(0.19)$ & $(0.12)$ & $(0.21)$ & $(0.46)$ & $(0.28)$ \\
\hline Observations & 1441 & 925 & 1441 & 1441 & 925 & 1441 \\
$R^{2}$ & 0.18 & 0.22 & 0.20 & 0.01 & 0.05 & 0.05 \\
\hline
\end{tabular}


We also asked respondents to make a decision with real stakes: we provided each subject with a 10 cent bonus and told them that they could choose to donate a portion of it to an animal welfare non-profit organization specializing in reducing harm to farm animals and that amount would be matched. For example, if they elected to give up 5 cents of their bonus, 10 cents would be donated. Again, the new products had no effect.

Other beliefs - beliefs about the material harm done to animals and the personal weight one places on that harm - also exhibited similar patterns (Table 2). It should be noted that the "belief about harm" variable is an index comprised of 2 questions; as pre-specified, we present results for the index but include disaggregated results in the Appendix (Table A1).

However, those who had more positive reactions to the new product or who thought it would be easy to reduce their consumption of conventional meat products did exhibit changes in their stated beliefs and also were more likely to make a donation to the animal welfare charity.

Interestingly, even though most of the information provided to respondents through the video dealt with harm to animals, beliefs about the environmental damage caused by conventional animal agriculture also changed.

Of the various types of messages tested (appeals to health, the environment, or animals' well-being), no message was more persuasive than any other message, except for environmental messages being more likely to change respondents' views as to the environmental harms of factory farming (Table A2).

We also asked respondents if they planned to reduce their consumption of conventional meat products and, if so, by how much. Results for these outcome variables are presented in Table 3. Subjects answered consistently in all cases: those who felt more positively towards

does not disentangle why participants might think eating vegetarian food is or is not morally preferable to eating conventional food products; in particular, it is possible that some participants might find eating vegetarian products morally preferable for environmental reasons and some might find it morally preferable due to the treatment of animals in factory farming. We phrased the question this way, rather than asking about whether it is morally preferable to not harm animals or to not harm the environment, because we suspected that almost all respondents would say that it is morally preferable to not harm animals and to not harm the environment. We may get a more meaningful measure of the moral weight people place on animals or the environment by positing the question in a situation in which they would be forced to make a tradeoff (assuming that most non-vegetarians at least sometimes prefer to not eat vegetarian food). 
the new product or felt like it would be easier to reduce their consumption of conventional meat products expected to reduce their meat consumption more.

One possible explanation for these results is that when people are faced with a "vegetarian" product, they perceive it in a moral framing, knowing many people are vegetarian for ethical reasons. Another possibility is that people who find it easier to change their beliefs about how easy it would be to reduce their meat consumption find it easier to change their beliefs more generally, and this correlation is broken in the group exposed to clean meat because other factors become more salient, such as health issues. In particular, those exposed to the clean meat treatment had been provided with an additional page with information on the process of how clean meat is made, and this additional information could have influenced people to think in a medical or health framing.

To explore these possibilities, we ran a second experiment in which we slightly changed the language used (from "cultured" to "clean" meat), and tested out different "ethical" and "process" framings. In particular, we explicitly primed $1 / 3$ of the respondents in the clean meat treatment group with an ethical framing, asking them the questions "Just like some people are vegetarian for ethical reasons, some people say they would prefer to eat clean meat for ethical reasons. Do you know any vegetarians personally?" and "Do you think you know anyone who might prefer to eat clean meat on ethical grounds?"; we also asked $1 / 2$ of those in the "vegetarian" and control arm: "Some people are vegetarian for ethical reasons. Do you know any vegetarians personally?" and "Do you think you know anyone who might prefer to be vegetarian on ethical grounds?" At the same time, we provided 1/3 of those who saw the clean meat treatment arm with more information about the process of producing clean meat, trying to nudge them away from learning about the product in an ethical framing. The randomization was done together with the randomization into the ethical framing, i.e., 1/3 received the ethical framing, 1/3 received the additional process details, and $1 / 3$ received neither framing.

We did not find support for the hypothesis that an ethical framing would change results. The ethical framing may have even nudged respondents away from changing their beliefs 
Table 2: Regression of Belief Change on Treatments

\begin{tabular}{|c|c|c|c|c|c|c|}
\hline \multicolumn{7}{|c|}{ Animal-related outcomes } \\
\hline & $\begin{array}{c}(1) \\
\text { Belief } \\
\text { about harm }\end{array}$ & $\begin{array}{c}(2) \\
\text { Belief } \\
\text { about harm }\end{array}$ & $\begin{array}{c}(3) \\
\text { Belief } \\
\text { about harm }\end{array}$ & $\begin{array}{c}(4) \\
\text { Importance } \\
\text { of harm }\end{array}$ & $\begin{array}{c}(5) \\
\text { Importance } \\
\text { of harm }\end{array}$ & $\begin{array}{c}\text { (6) } \\
\text { Importance } \\
\text { of harm }\end{array}$ \\
\hline Clean meat & $\begin{array}{l}-0.030 \\
(0.07)\end{array}$ & & & $\begin{array}{l}0.004 \\
(0.06)\end{array}$ & & \\
\hline $\begin{array}{l}\text { Vegetarian } \\
\text { substitute }\end{array}$ & $\begin{array}{c}-0.137^{*} \\
(0.07)\end{array}$ & & $\begin{array}{l}-0.101 \\
(0.07)\end{array}$ & $\begin{array}{l}-0.010 \\
(0.06)\end{array}$ & $\begin{array}{l}0.041 \\
(0.06)\end{array}$ & $\begin{array}{l}0.021 \\
(0.05)\end{array}$ \\
\hline Positivity index & & $\begin{array}{c}0.054^{* * *} \\
(0.01)\end{array}$ & & & $\begin{array}{c}0.052^{* * *} \\
(0.01)\end{array}$ & \\
\hline Easiness index & & & $\begin{array}{c}0.035^{* * *} \\
(0.01)\end{array}$ & & & $\begin{array}{c}0.042^{* * * *} \\
(0.01)\end{array}$ \\
\hline Baseline value & $\begin{array}{c}-0.441^{* * *} \\
(0.02)\end{array}$ & $\begin{array}{c}-0.466^{* * *} \\
(0.03)\end{array}$ & $\begin{array}{c}-0.460^{* * *} \\
(0.02)\end{array}$ & $\begin{array}{c}-0.332^{* * *} \\
(0.02)\end{array}$ & $\begin{array}{c}-0.391^{* * *} \\
(0.03)\end{array}$ & $\begin{array}{c}-0.375^{* * *} \\
(0.02)\end{array}$ \\
\hline $\begin{array}{l}\text { Baseline meat } \\
\text { consumption }\end{array}$ & $\begin{array}{c}-0.006^{* *} \\
(0.00)\end{array}$ & $\begin{array}{c}-0.006^{*} \\
(0.00)\end{array}$ & $\begin{array}{c}-0.005^{*} \\
(0.00)\end{array}$ & $\begin{array}{r}-0.002 \\
(0.00)\end{array}$ & $\begin{array}{r}-0.001 \\
(0.00)\end{array}$ & $\begin{array}{r}-0.001 \\
(0.00)\end{array}$ \\
\hline Constant & $\begin{array}{c}4.539^{* * * *} \\
(0.20)\end{array}$ & $\begin{array}{c}4.048^{* * * *} \\
(0.26)\end{array}$ & $\begin{array}{c}4.416^{* * *} \\
(0.20)\end{array}$ & $\begin{array}{c}1.812^{* * * *} \\
(0.08)\end{array}$ & $\begin{array}{c}1.373^{* * * *} \\
(0.12)\end{array}$ & $\begin{array}{c}1.625^{* * * *} \\
(0.08)\end{array}$ \\
\hline Observations & 1441 & 925 & 1441 & 1441 & 925 & 1441 \\
\hline$R^{2}$ & 0.31 & 0.31 & 0.32 & 0.17 & 0.20 & 0.19 \\
\hline \multicolumn{7}{|c|}{ Environmental outcomes } \\
\hline & $(1)$ & $(2)$ & $(3)$ & $(4)$ & $(5)$ & $(6)$ \\
\hline & $\begin{array}{c}\text { Belief } \\
\text { about harm }\end{array}$ & $\begin{array}{c}\text { Belief } \\
\text { about harm }\end{array}$ & $\begin{array}{c}\text { Belief } \\
\text { about harm }\end{array}$ & $\begin{array}{l}\text { Importance } \\
\text { of harm }\end{array}$ & $\begin{array}{l}\text { Importance } \\
\text { of harm }\end{array}$ & $\begin{array}{l}\text { Importance } \\
\text { of harm }\end{array}$ \\
\hline Clean meat & $\begin{array}{l}-0.008 \\
(0.09)\end{array}$ & & & $\begin{array}{l}-0.058 \\
(0.06)\end{array}$ & & \\
\hline $\begin{array}{l}\text { Vegetarian } \\
\text { substitute }\end{array}$ & $\begin{array}{r}-0.091 \\
(0.09)\end{array}$ & & & $\begin{array}{l}-0.034 \\
(0.06)\end{array}$ & & \\
\hline Positivity index & & $\begin{array}{c}0.092^{* * *} \\
(0.02)\end{array}$ & & & $\begin{array}{c}0.055^{* * * *} \\
(0.01)\end{array}$ & \\
\hline Easiness index & & & $\begin{array}{c}0.102^{* * *} \\
(0.01)\end{array}$ & & & $\begin{array}{c}0.058^{* * *} \\
(0.01)\end{array}$ \\
\hline Baseline value & $\begin{array}{c}-0.269^{* * *} \\
(0.02)\end{array}$ & $\begin{array}{c}-0.337^{* * *} \\
(0.03)\end{array}$ & $\begin{array}{c}-0.326^{* * *} \\
(0.02)\end{array}$ & $\begin{array}{c}-0.239^{* * *} \\
(0.02)\end{array}$ & $\begin{array}{c}-0.301^{* * *} \\
(0.03)\end{array}$ & $\begin{array}{c}-0.300^{* * * *} \\
(0.02)\end{array}$ \\
\hline $\begin{array}{l}\text { Baseline meat } \\
\text { consumption }\end{array}$ & $\begin{array}{l}0.002 \\
(0.00)\end{array}$ & $\begin{array}{l}0.001 \\
(0.00)\end{array}$ & $\begin{array}{l}0.003 \\
(0.00)\end{array}$ & $\begin{array}{c}-0.004^{* *} \\
(0.00)\end{array}$ & $\begin{array}{c}-0.004^{*} \\
(0.00)\end{array}$ & $\begin{array}{c}-0.003 \\
(0.00)\end{array}$ \\
\hline Constant & $\begin{array}{c}2.692^{* * * *} \\
(0.17)\end{array}$ & $\begin{array}{c}2.083^{* * *} \\
(0.20)\end{array}$ & $\begin{array}{c}2.323^{* * *} \\
(0.15)\end{array}$ & $\begin{array}{c}1.396^{* * * *} \\
(0.08)\end{array}$ & $\begin{array}{c}0.909^{* * *} \\
(0.11)\end{array}$ & $\begin{array}{c}1.110^{* * * *} \\
(0.07)\end{array}$ \\
\hline Observations & 1441 & 925 & 1441 & 1441 & 925 & 1441 \\
\hline$R^{2}$ & 0.13 & 0.18 & 0.17 & 0.09 & 0.13 & 0.12 \\
\hline
\end{tabular}


Table 3: Regression of Changes in Expected Consumption on Treatments

\begin{tabular}{|c|c|c|c|c|c|c|}
\hline & $\begin{array}{c}(1) \\
\text { Expects } \\
\text { to reduce } \\
\text { consumption }\end{array}$ & $\begin{array}{c}(2) \\
\text { Expects } \\
\text { to reduce } \\
\text { consumption }\end{array}$ & $\begin{array}{c}(3) \\
\text { Expects } \\
\text { to reduce } \\
\text { consumption }\end{array}$ & $\begin{array}{l}\quad(4) \\
\text { How much } \\
\text { expects to } \\
\text { reduce }\end{array}$ & $\begin{array}{l}\quad(5) \\
\text { How much } \\
\text { expects to } \\
\text { reduce }\end{array}$ & $\begin{array}{l}\quad(6) \\
\text { How much } \\
\text { expects to } \\
\text { reduce }\end{array}$ \\
\hline Clean meat & $\begin{array}{l}-0.234 \\
(0.22)\end{array}$ & & & $\begin{array}{l}-0.279 \\
(0.21)\end{array}$ & & \\
\hline $\begin{array}{l}\text { Vegetarian } \\
\text { substitute }\end{array}$ & $\begin{array}{l}-0.242 \\
(0.22)\end{array}$ & & & $\begin{array}{l}-0.206 \\
(0.21)\end{array}$ & & \\
\hline Positivity index & & $\begin{array}{c}0.279^{* * *} \\
(0.03)\end{array}$ & & & $\begin{array}{c}0.268^{* * *} \\
(0.03)\end{array}$ & \\
\hline Easiness index & & & $\begin{array}{c}0.493^{* * *} \\
(0.03)\end{array}$ & & & $\begin{array}{c}0.477^{* * *} \\
(0.02)\end{array}$ \\
\hline $\begin{array}{l}\text { Baseline meat } \\
\text { consumption }\end{array}$ & $\begin{array}{c}-0.016^{* *} \\
(0.01)\end{array}$ & $\begin{array}{r}-0.012 \\
(0.01)\end{array}$ & $\begin{array}{r}-0.006 \\
(0.01)\end{array}$ & $\begin{array}{c}-0.012^{*} \\
(0.01)\end{array}$ & $\begin{array}{l}-0.011 \\
(0.01)\end{array}$ & $\begin{array}{c}-0.003 \\
(0.01)\end{array}$ \\
\hline Constant & $\begin{array}{c}6.161^{* * *} \\
(0.17)\end{array}$ & $\begin{array}{c}2.763^{* * *} \\
(0.37)\end{array}$ & $\begin{array}{c}2.462^{* * *} \\
(0.20)\end{array}$ & $\begin{array}{c}5.695^{* * *} \\
(0.17)\end{array}$ & $\begin{array}{c}2.439^{* * *} \\
(0.35)\end{array}$ & $\begin{array}{c}2.109^{* * *} \\
(0.19)\end{array}$ \\
\hline Observations & 1441 & 925 & 1441 & 1441 & 925 & 1441 \\
\hline$R^{2}$ & 0.00 & 0.10 & 0.23 & 0.00 & 0.10 & 0.23 \\
\hline
\end{tabular}

(Table A3).

Finally, we leveraged the randomized priming of respondents with negative social information about clean meat to determine whether the observed relationship between having a more positive perception of clean meat and changing one's ethical views was causal.

Table 4 shows the first stage of this instrument against the positivity index (strong instrument) and the easiness index (weak instrument); we will only use it to capture how positively a subject felt about the product. Table 5 presents the second stage regressions of changes in beliefs, using this instrument. Donations were not solicited in this experiment, but we do see some evidence that those not primed to think of the naturalistic heuristic were more likely to say that it was morally preferable to be vegetarian and to place more personal weight on the harm they perceived done to animals.

These results are intriguing and suggest it will not be straightforward for clean meat to by itself change ethical beliefs. Further work could explore whether these results hold in other contexts. In particular, while this study appears to show that clean meat does not change beliefs relating to animals or the environment when people are first introduced to 
it, it is possible that if clean meat became broadly popular it could have different effects.

It may also be argued that by priming some respondents to consider the naturalistic heuristic, their responses may not accurately represent how consumers would feel about clean meat. We note that many respondents raised concerns about the "unnaturalness" of clean meat on their own; further, it is unrealistic to think that when clean meat becomes commercially available, the meat industry would not push back with attack ads referencing the naturalistic heuristic. Thus, we believe this concern is a real issue that clean meat firms will have to address.

Table 4: First Stage: Regression of Positivity and Easiness Indices on No Negative Information Treatment

\begin{tabular}{lcc}
\hline & $(1)$ & $(2)$ \\
& Positivity index & Easiness index \\
\hline No negative & $1.218^{* * *}$ & 0.147 \\
information & $(0.17)$ & $(0.14)$ \\
Baseline meat & -0.002 & $-0.027^{* * *}$ \\
consumption & $(0.01)$ & $(0.01)$ \\
Constant & $10.472^{* * *}$ & $6.727^{* * *}$ \\
& $(0.15)$ & $(0.11)$ \\
\hline Observations & 2065 & 2065 \\
\hline
\end{tabular}

Table 5: Second Stage: Regression of Change in Beliefs on Predicted Positivity Index

\begin{tabular}{|c|c|c|c|c|c|}
\hline & \multirow[b]{2}{*}{$\begin{array}{c}(1) \\
\text { Morally } \\
\text { preferable }\end{array}$} & \multicolumn{2}{|c|}{ Animal-related outcomes } & \multicolumn{2}{|c|}{ Environmental outcomes } \\
\hline & & $\begin{array}{c}(2) \\
\text { Belief } \\
\text { about harm }\end{array}$ & $\begin{array}{c}(3) \\
\text { Importance } \\
\text { of harm }\end{array}$ & $\begin{array}{c}(4) \\
\text { Belief } \\
\text { about harm }\end{array}$ & $\begin{array}{c}(5) \\
\text { Importance } \\
\text { of harm }\end{array}$ \\
\hline Positivity index & $\begin{array}{c}0.141^{* * *} \\
(0.05)\end{array}$ & $\begin{array}{l}0.045 \\
(0.04)\end{array}$ & $\begin{array}{c}0.059^{* *} \\
(0.03)\end{array}$ & $\begin{array}{l}0.019 \\
(0.05)\end{array}$ & $\begin{array}{l}0.021 \\
(0.03)\end{array}$ \\
\hline $\begin{array}{l}\text { Baseline meat } \\
\text { consumption }\end{array}$ & $\begin{array}{c}0.004 \\
(0.00)\end{array}$ & $\begin{array}{l}0.003 \\
(0.00)\end{array}$ & $\begin{array}{c}-0.004^{* *} \\
(0.00)\end{array}$ & $\begin{array}{l}-0.001 \\
(0.00)\end{array}$ & $\begin{array}{c}-0.004^{* *} \\
(0.00)\end{array}$ \\
\hline Constant & $\begin{array}{c}-2.540^{* * * *} \\
(0.57) \\
\end{array}$ & $\begin{array}{c}-0.882^{* *} \\
(0.42)\end{array}$ & $\begin{array}{c}-0.990^{* * * *} \\
(0.33)\end{array}$ & $\begin{array}{l}-0.501 \\
(0.53)\end{array}$ & $\begin{array}{l}-0.403 \\
(0.34)\end{array}$ \\
\hline Observations & 2065 & 2065 & 2065 & 2065 & 2065 \\
\hline
\end{tabular}




\section{Conclusion}

Consumers face a myriad of ethical choices, often selecting the less ethical option and resolving the resulting dissonance through rationalization or willful ignorance. In this study, we examine whether providing consumers with higher quality or more convenient ethical goods reduces these incentives for rationalization, leading consumers to select ethical options more frequently and soften the attitudes and beliefs they hold to justify the less ethical option.

Through a pair of MTurk experiments in which participants were exposed to information about "clean" meat, conventional meat substitutes, or no new product at all, we find that clean meat does not on average lead to changes in ethical beliefs, but this appears due in large part to the high proportion of respondents that deem it to not be a good substitute for conventional animal products. When we experimentally vary how positively respondents view clean meat, we find that those induced to think more positively do seem to change their ethical beliefs. In sum, though clean meat has the potential to reduce environmental degradation and animal suffering through direct substitution effects, producers of ethical goods should expect that the introduction of their products to market may not in and of itself create additional demand and at least in the short run it could even worsen the response to advocates' messages. 


\section{References and Notes}

Aarestrup, Frank M. (2005). "Veterinary Drug Usage and Antimicrobial Resistance in Bacteria of Animal Origin." Basic \& Clinical Pharmacology \& Toxicology 96 (4): 27181. doi:10.1111/j.1742-7843.2005.pto960401.x.

Addady, Michal (2016). "You Could Be Eating Lab-Grown Meat in Just Five Years." Fortune. February 2, 2016. Retrieved from: fortune.com.

Animal Legal Defense Fund (2017). "Farmed animals and the law", http://aldf.org/resources/advocating-for-animals/farmed-animals-and-the-law/ (Accessed on 10 March 2017).

Bekker, Gerben et al. (2017). "Explicit and implicit attitude toward an emerging food technology: The case of cultured meat." Appetite, vol. 108: 245254.

http://doi.org/10.1016/j.appet.2016.10.002.

FAO (2006). "Livestock's long shadow: Environmental issues and options".

Ferdman, Roberto A. (2015). "This is the future of meat." Washington Post. May 20, 2015. Retrieved from: www.washingtonpost.com.

Garfield, Leanna (2017). "Hampton Creek says it's making lab-grown meat that will be in supermarkets by 2018.” Business Insider. June 27, 2017. Retrieved from:

www.businessinsider.com.

Goodland, Robert and Jeff Anhang (2009). "Livestock and Climate Change", World Watch.

Ledford, Heidi (2012). "FDA approves its first egg-free seasonal flu vaccine", Nature Blogs. Macfarlane, Jamie (2016). "Perceptions of plant-based and clean meat", presentation at the Good Food Institute, 11 November 2016.

Mattick, Carolyn, et al. (2015). "Anticipatory Life Cycle Analysis of In Vitro Biomass Cultivation for Cultured Meat Production in the United States", Environmental Science and Technology, vol. 49(19). doi: 10.1021/acs.est.5b01614.

Nyhan, B. and J. Reifler (2015). "Does correcting myths about the flu vaccine work? An experimental evaluation of the effects of corrective information." Vaccine 33, 459464. 
Nyhan, B., J. Reifler, S. Richey, and G. L. Freed (2014). "Effective messages in vaccine promotion: A randomized trial." Pediatrics.

OECD (2017), Meat consumption (indicator). doi: 10.1787/fa290fd0-en (Accessed on 10 March 2017).

Rabin, Matthew (1994). "Cognitive dissonance and social change", Journal of Economic Behavior and Organization, vol. 23: 177-194.

Riffkin, Rebecca (2015). "In U.S., More Say Animals Should Have Same Rights as People", Social Issues.

http://www.gallup.com/poll/183275/say-animals-rights-people.aspx

Steg, Linda and Charles Vlek (2009). "Encouraging Pro-Environmental Behaviour: An

Integrative Review And Research Agenda." Journal of Environmental Psychology, 29(3), 309-317.

Stone, Maddie (2016). "The Future Will Be Full of Lab Grown Meat." Gizmodo. May 27, 2016. Retrieved from: gizmodo.com.

Tuomisto, Hanna and M. Joost Teixeira de Mattos (2011). "Environmental Impacts of Cultured Meat Production", Environmental Science and Technology, vol. 45(4). doi: 10.1021/es200130u.

Tuomisto, Hanna and Avijit Roy (2012). "Could cultured meat reduce environmental impact of agriculture in Europe?" 8th International Conference on LCA in the Agri-Food Sector, Rennes, France, 2-4 October 2012.

Verbeke, Wim, Pierre Sans, and Ellen J. Van Loo. (2015). "Challenges and prospects for consumer acceptance of cultured meat", Journal of Integrative Agriculture, vol. 14.2: $285-294$.

Verbeke, Wim, et al. (2015). “'Would you eat cultured meat?': Consumers' reactions and attitude formation in Belgium, Portugal and the United Kingdom." Meat science, vol. 102: 49-58. http://doi.org/10.1016/j.meatsci.2014.11.013.

Vieira, Antonio R., Peter Collignon, Frank M. Aarestrup, Scott A. McEwen, Rene S. Hendriksen, Tine Hald, and Henrik C. Wegener (2011). “Association between 
Antimicrobial Resistance in Escherichia Coli Isolates from Food Animals and Blood Stream Isolates from Humans in Europe: An Ecological Study." Foodborne Pathogens and Disease 8 (12): 12951301. doi:10.1089/fpd.2011.0950.

Wang, Brian (2017). "Lab grown meat prices have dropped 30,000 times in less than four years and are about 3-4 times more expensive than regular ground beef." Next Big Future. February 19, 2017. Retrieved from: www.nextbigfuture.com. World Health Organization (2017). "Six common misconceptions about immunization." Retrieved from: www.who.int.

Wilks, Matti and Clive Phillips (2017). "Attitudes to in vitro meat: A survey of potential consumers in the United States", PLOS ONE.

http://dx.doi.org/10.1371/journal.pone.0171904 


\section{Appendix}

\section{Experimental Design}

Subjects were randomized into one of three "product" treatment arms (clean meat, vegetarian subsitute, no new product) and one of three "message" treatment arms (health, environmental, ethical). The text and images used in each of the arms is reproduced below. 
Figure A1: Treatment Arm 1: Clean meat x Health message

Animal agriculture poses significant health risks to humanity, including the spread of disease, antibiotic overuse and bacterial contamination. Cultured meat - that is, real meat grown from animal cells without the need to raise and slaughter an actual animal-offers significant benefits in this respect, and is currently being developed by several startup companies.

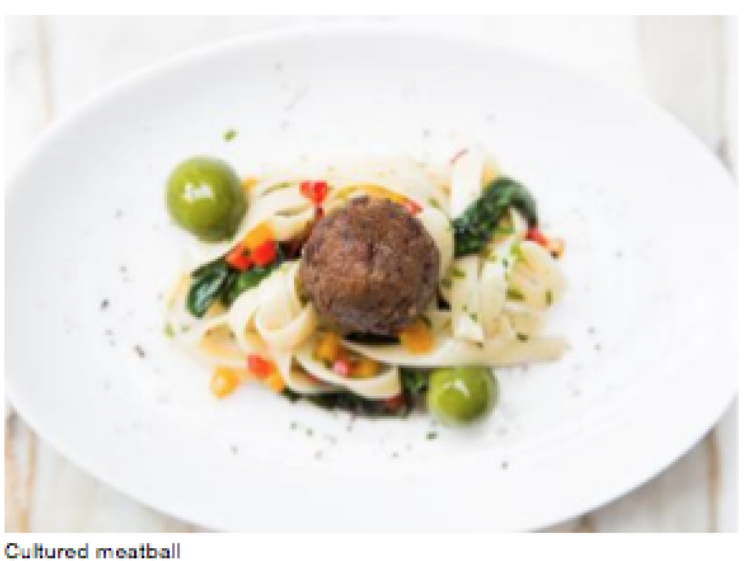

meatbal

The process is simple:

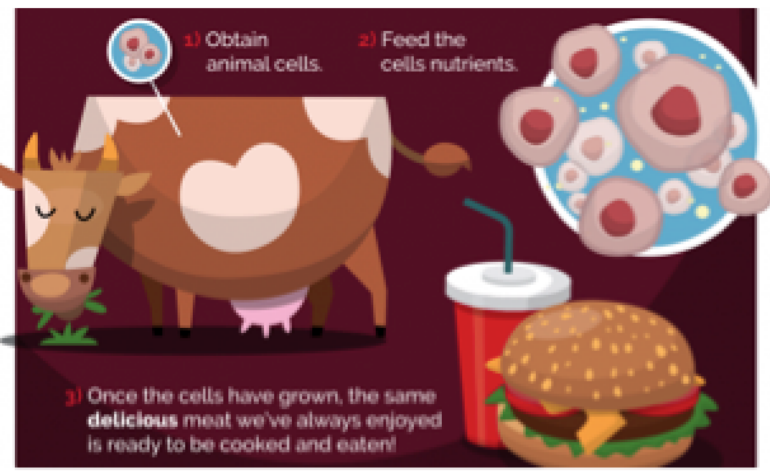

Some of the public health benefits of cultured meat include:

- Antibiotio resistance: $80 \%$ of antibiotios used in the United States are used on farm animals.[1] This averuso of antibiotics causes bacteria to evolve and become antibiotic-rosistant. In November 2015, a superbug was discovered that is resistant to even our last resort antibiotics; this is believed to be a result of the overuse of antibiotics in animal agrieulture. In May 2016, the superbug was detected for the first time in the US, prompting the director of the Center for Disease Control to claim that "the end of the road isn't very far away for antibiotics."[2] Cultured meat is expected to reduce or eliminate the use of antibiotics in meat production.

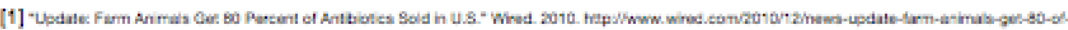

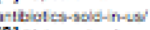

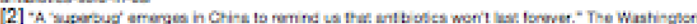

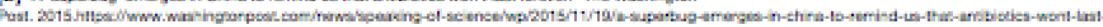
lonavir

- Disease: Animal epidemios are common in animal agriculture, including avian flu, mad cow disease and swine flu. Because cultured meat does not require actual animals, this is not a concern.

- Bacterial contamination: The process of slaughtering an animal areates a myriad of potential avenues for contamination. Consumer Reports inspected 458 pounds of ground beef from a variety of sources, and found that all of it contained fecal contamination.[1] Other common sources of contamination include salmanella and $E$. coli. Because cultured meat is produoed in a sterile environment and does not require slaughtering an animal, risk of bacterial contamination is greatly reduced.

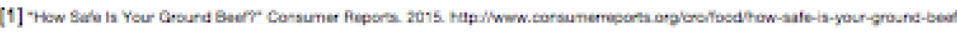


Figure A2: Treatment Arm 2: Vegetarian substitute x Health message

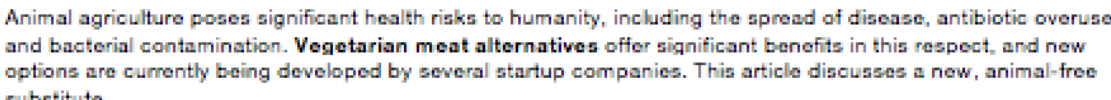
options are currently being developed by several startup companies. This article discusses a new, animal-free substitute.

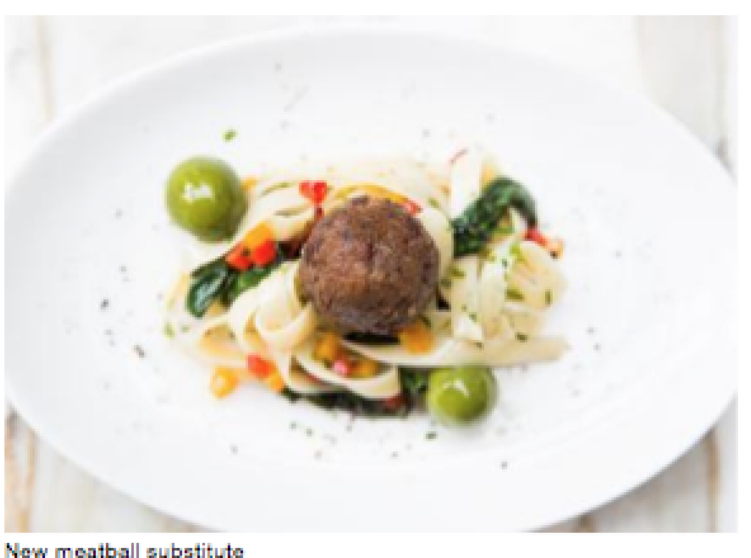

Now meatball substitute

Some of the public health benefits of this product include:

- Antibiotio resistance: $80 \%$ of antibiotios used in the United States are used on farm animals.[1] This averuse of antibiotics ouuses bacteria to evolve and become antibiotio-rosistant. In November 2015, a superbug was discovered that is resistant to aven our last resort antibiotics; this is believed to be a result of the overuse of antibiotics in animal agrioulture. In May 2016, the superbug was detected for the first time in the US, prompting the director of the Center for Disease Control to claim that "the end of the road isn't very far away for antibiotics."[2] This substitute is expected to reduce or eliminate the use of antibiotics in meat production.

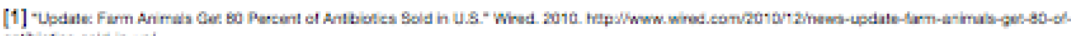

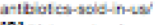

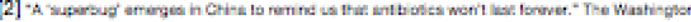

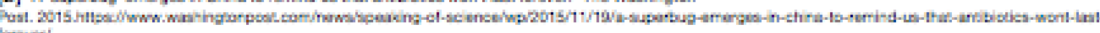

- Disease: Animal epidemios are common in animal apriculture, including avian flu, mad cow disease and swine flu. Because this substitute does not require actual animals, this is not a concern.

- Bacterial contamination: The process of slaughtering an animal creates a myriad of potential avenues for contamination. Consumer Reports inspected 459 pounds of ground beef from a variaty of sources, and found that all of it oontained fecal contamination.[1] Other common sources of contamination include salmonella and $E$. coli. Because this substitute is produced in a sterile environment and does not require slaughtering an animal, risk of bacterial contamination is greatly reduced.

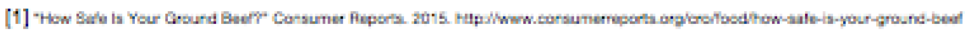


Figure A3: Treatment Arm 3: No new product x Health message

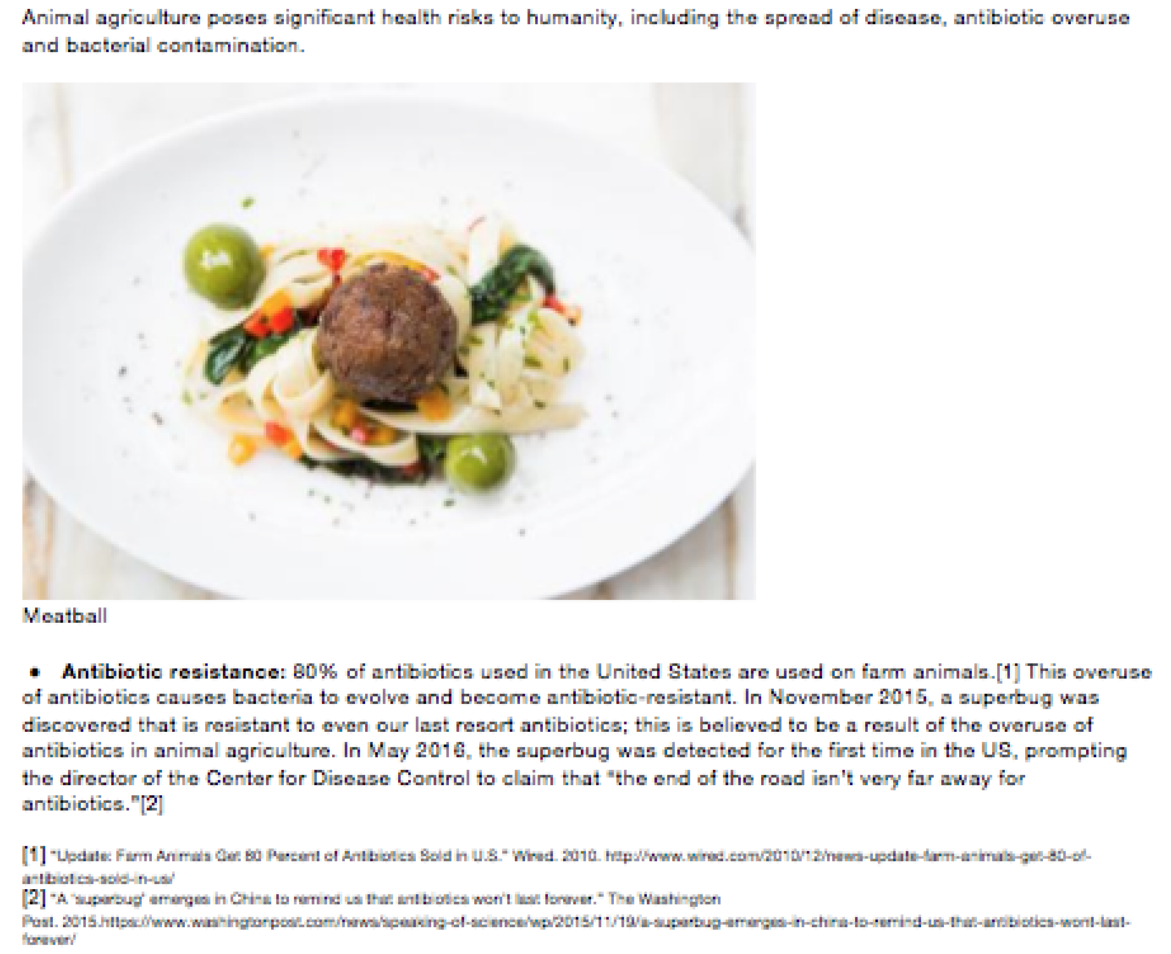

- Disease: Animal epidemios are common in animal agriculture, including avian flu, mad cow disease and swine flu.

- Bacterial contamination: The process of slaughtering an animal creates a myriad of potential avenues for contamination. Consumer Reports inspected 459 pounds of ground beef from a variety of sources, and found that all of it contained fecal contamination.[1] Other common sources of contamination include salmonella and $E$. coli.

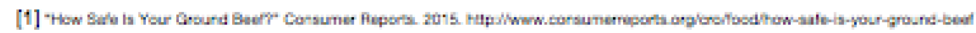


Figure A4: Treatment Arm 4: Clean meat x Environmental message

Animal agriculture is one of the most environmentally destructive industries in the world. With the global population expected to reach 9.7 billion by 2050 , and meat produotion expected to double in that time, organizations like the United Nations are urging populations to eat less meat. However, all indicators suggest that meat demand will continue to rise despite these warnings. Cultured meat-that is, real meat grown from animal cells without the need to raise and slaughter an actual animal-offers significant benefits in this respect. and is aurrently being developed by several startup companies.

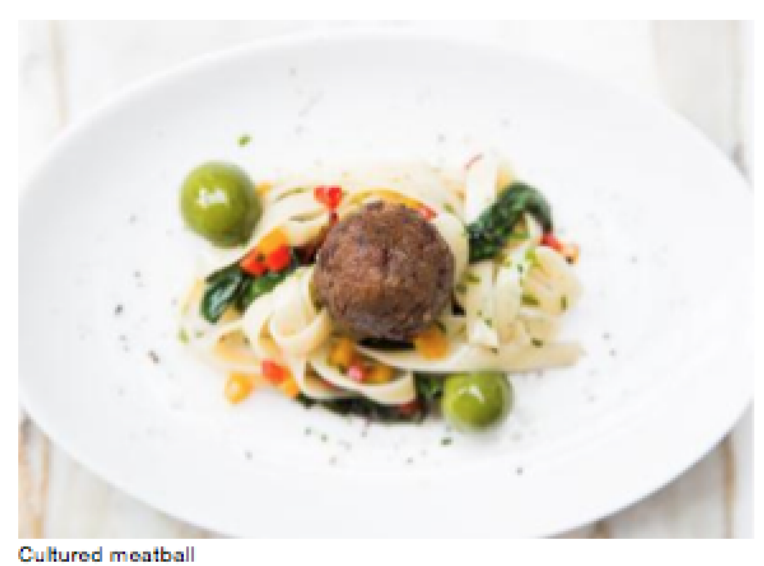

The process is simple:

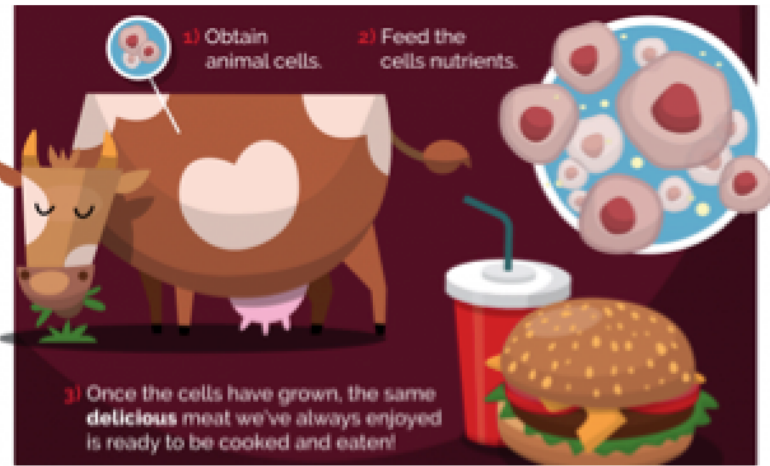

Specifically, cultured meat can help with:

- Climate ohange: Animal agriculture is responsible for anywhere from 14 to $51 \%$ of all greenhouse gas emissions; cultured meat requires up to $99 \%$ less greenhouse gas emissions than conventionally-produced meat[1]

$[1] \cdot 3$

- Water: A conventionally-produced hamburger requires roughly 660 gallons of water, aultured meat requires up to $96 \%$ less water[1]

$[1] \cdot$

- Land: One-third of the habitable land on earth is currently devoted to animal agriculture; cultured meat requires $99 \%$ less land[1]

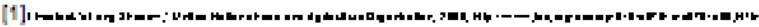


Figure A5: Treatment Arm 5: Vegetarian substitute x Environmental message

\begin{abstract}
Animal agriculture is one of the most environmentally destructive industries in the world. With the global population expected to reach 9.7 billion by 2050 , and meat production expected to double in that time, organizations like the United Nations are urging populations to eat less meat. However, all indioators suggest that meat demand will continue to rise despite these warnings. Vegetarian meat alternatives offer significant benefits in this respect, and new options are currently being developed by several startup companies. This article discusses a new, animal-free substitute.
\end{abstract}

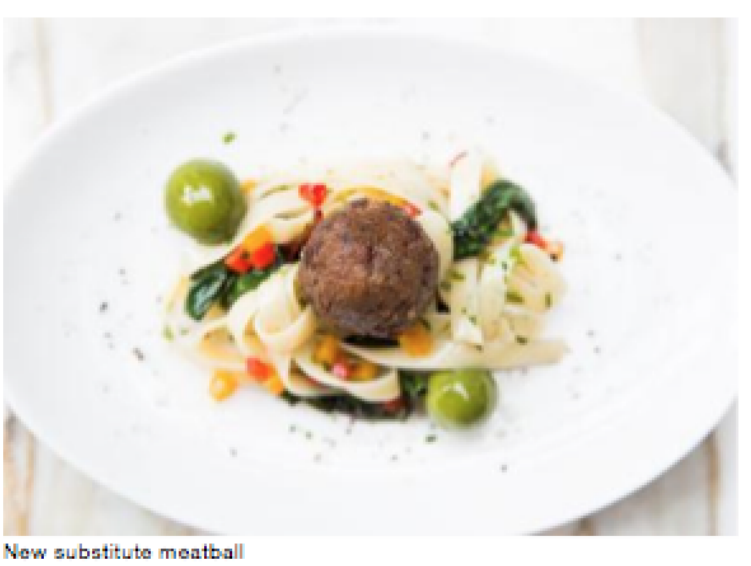

Specifically, this product can help with:

- Climate change: Animal agriculture is responsible for anywhere from 14 to $51 \%$ of all greenhouse gas emissions; this substitute requires up to $99 \%$ less greenhouse gas emissions than conventionally-produced meat[1]

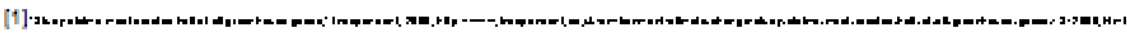

- Water: A conventionally-produced hamburger requires roughly 690 gallons of water; this substitute requires up to $96 \%$ less water[1]

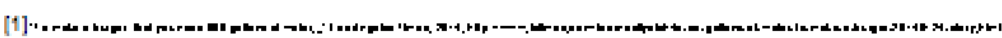

- Land: One-third of the habitable land on earth is currently devoted to animal agriculture; this substitute requires $99 \%$ less land[1]

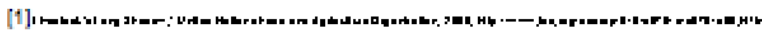


Figure A6: Treatment Arm 6: No new product x Environmental message

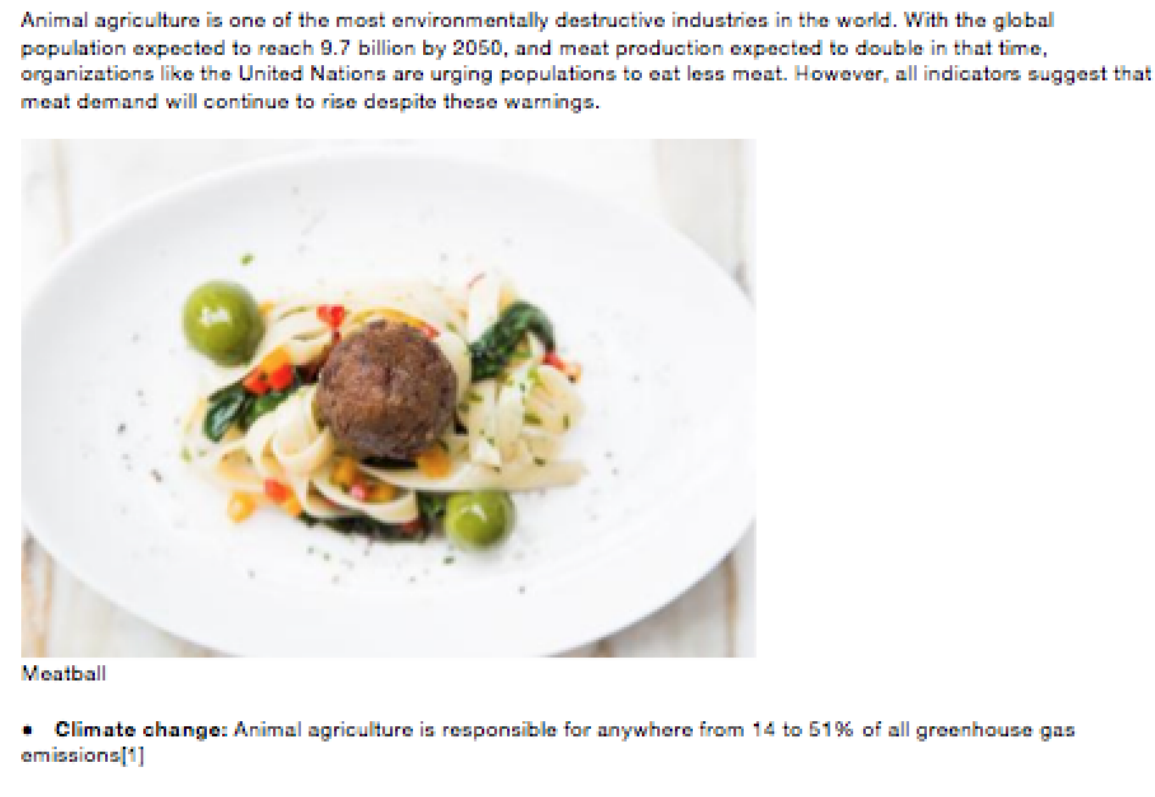

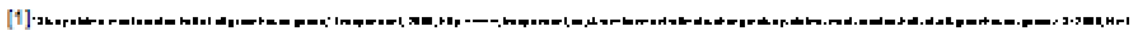

- Water: A conventionally-produced hamburger requires roughly 640 gallons of water[1]

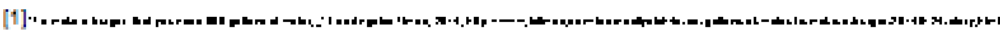

- Land: One-third of the habitable land on earth is currently devoted to animal agriculture["]

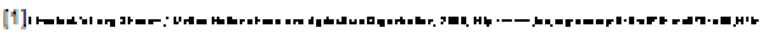


Figure A7: Treatment Arm 7: Clean meat x Ethical message

\begin{abstract}
Since the post-war period, increased demand for meat has forced suppliers to make meat production more efficient. While this has allowed meat supply to match meat demand, it is often done at the expense of the factory farmed pigs, chickens and cows - animals that are just as capable of suffering as the dogs and cats we love. Each year, hundreds of billions of animals are raised for food, and most of them endure immense amounts of suffering. Cultured meat-that is, real meat grown from animal cells without the need to raise and slaughter an actual animal-offers significant benefits in this respect, and is currently being developed by several startup aompanies.
\end{abstract}

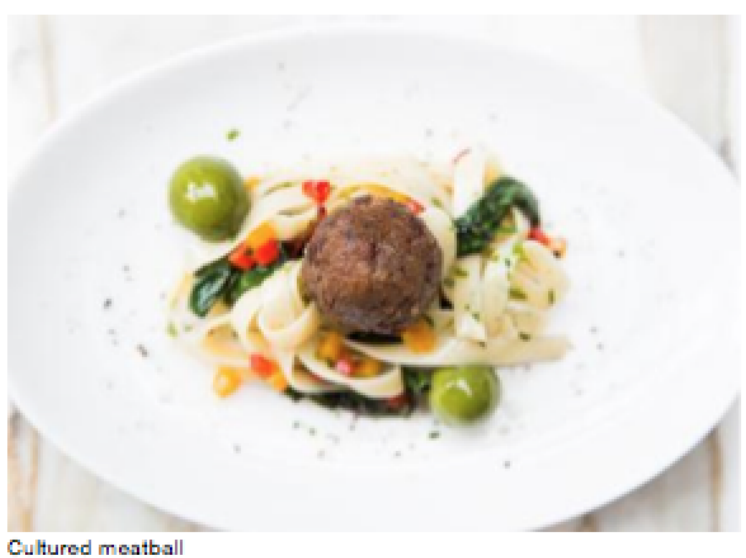

The process is simple:

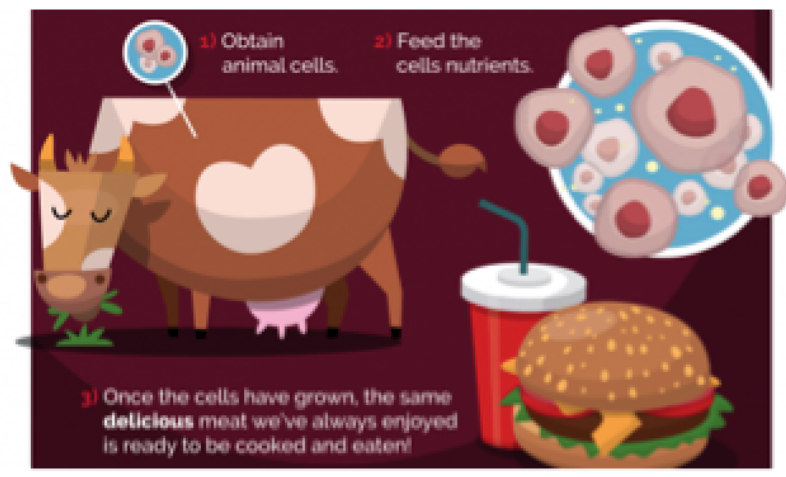

The harm done to animals in the creation of conventional meat products that would be avoided with cultured meat includes:

- Confinement in small aages: Farm animals are often kept in cages so small they are unable to turn around or fully extend their limbs. This also provents them from engaging in natural behaviors[1]

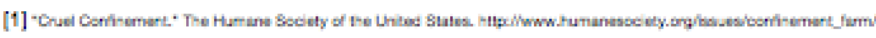

- Surgioal mutilations: Animals routinely face custration or debeaking without painkillers[1]

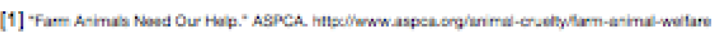

- Slaughter: Animals are often killed while fully conscious[1]

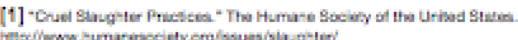


Figure A8: Treatment Arm 8: Vegetarian substitute x Ethical message

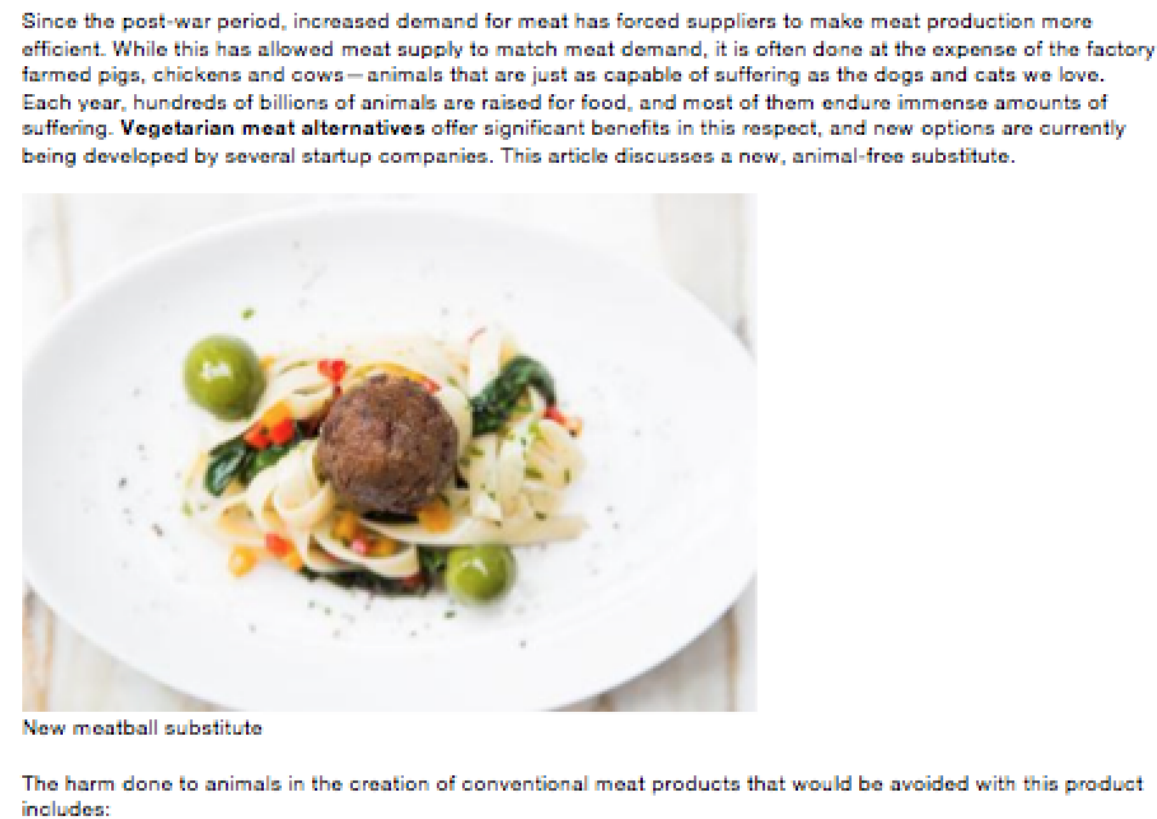
includes:

- Confinement in small aages: Farm animals are often kept in cages so small they are unable to turn around or fully extend their limbs. This also prevents them from engaging in natural behaviors[1]

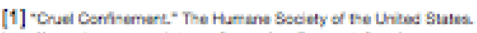

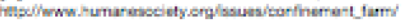

- Surgical mutilation: Animals routinaly face castration or debeaking without painkillers[1]

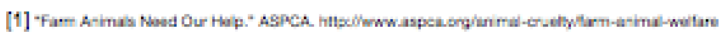

- Slaughter: Animals are often killed while fully conscious[1]

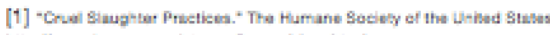

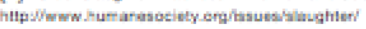


Figure A9: Treatment Arm 9: No new product x Ethical message

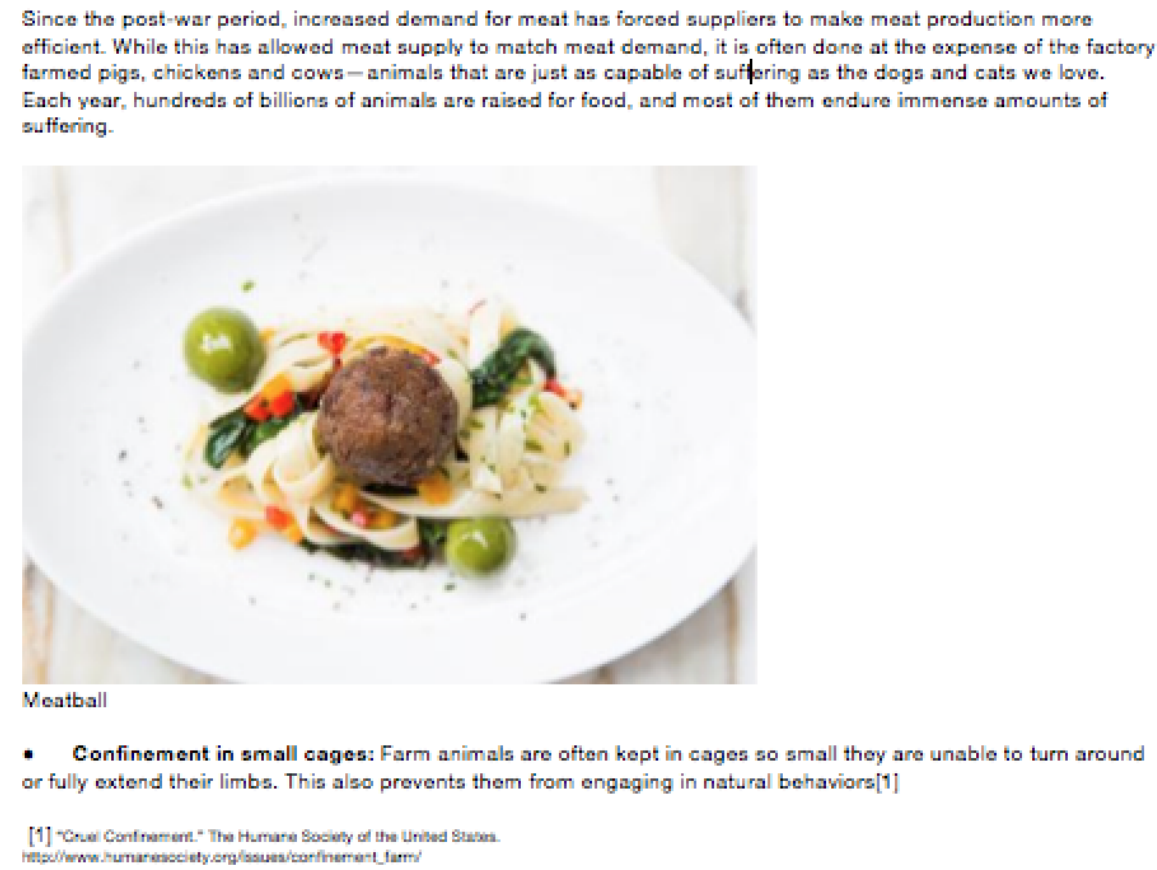

- Surgioal mutilation: Animals routinely face castration or debeaking without painkillers[1]

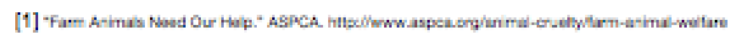

- Slaughter: Animals are often killed while fully conscious[1]

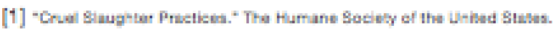

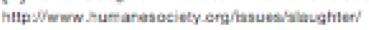


Additional Tables 
Table A1: Regression of Change in Beliefs on Treatments, Disaggregated

\begin{tabular}{|c|c|c|c|c|c|c|}
\hline \multicolumn{7}{|c|}{ Environmental outcomes } \\
\hline & $(1)$ & $(2)$ & $(3)$ & (4) & $(5)$ & $(6)$ \\
\hline & Sentient & Sentient & Sentient & $\begin{array}{l}\text { How much } \\
\text { harm }\end{array}$ & $\begin{array}{l}\text { How much } \\
\text { harm }\end{array}$ & $\begin{array}{l}\text { How much } \\
\text { harm }\end{array}$ \\
\hline Clean meat & $\begin{array}{l}-0.032 \\
(0.04)\end{array}$ & & & $\begin{array}{l}0.006 \\
(0.05)\end{array}$ & & \\
\hline Vegetarian & -0.046 & & & -0.085 & & \\
\hline substitute & $(0.03)$ & & & $(0.05)$ & & \\
\hline Positivity index & & $\begin{array}{c}0.016^{* * *} \\
(0.01)\end{array}$ & & & $\begin{array}{c}0.044^{* * *} \\
(0.01)\end{array}$ & \\
\hline Easiness index & & & $\begin{array}{c}0.013^{* * *} \\
(0.00)\end{array}$ & & & $\begin{array}{c}0.031^{* * *} \\
(0.01)\end{array}$ \\
\hline Baseline value & $\begin{array}{c}-0.482^{* * *} \\
(0.03)\end{array}$ & $\begin{array}{c}-0.472^{* * *} \\
(0.03)\end{array}$ & $\begin{array}{c}-0.490^{* * *} \\
(0.03)\end{array}$ & $\begin{array}{c}-0.490^{* * *} \\
(0.02)\end{array}$ & $\begin{array}{c}-0.534^{* * *} \\
(0.03)\end{array}$ & $\begin{array}{c}-0.519^{* * * *} \\
(0.02)\end{array}$ \\
\hline $\begin{array}{l}\text { Baseline meat } \\
\text { consumption }\end{array}$ & $\begin{array}{r}-0.002 \\
(0.00)\end{array}$ & $\begin{array}{r}-0.001 \\
(0.00)\end{array}$ & $\begin{array}{r}-0.002 \\
(0.00)\end{array}$ & $\begin{array}{c}-0.004^{* *} \\
(0.00)\end{array}$ & $\begin{array}{c}-0.004^{*} \\
(0.00)\end{array}$ & $\begin{array}{c}-0.003^{*} \\
(0.00)\end{array}$ \\
\hline Constant & $\begin{array}{c}2.448^{* * * *} \\
(0.12)\end{array}$ & $\begin{array}{c}2.185^{* * * *} \\
(0.17)\end{array}$ & $\begin{array}{c}2.369^{* * * *} \\
(0.12)\end{array}$ & $\begin{array}{c}2.442^{* * *} \\
(0.10)\end{array}$ & $\begin{array}{c}2.076^{* * *} \\
(0.13)\end{array}$ & $\begin{array}{c}2.292^{* * *} \\
(0.09)\end{array}$ \\
\hline Observations & 1441 & 925 & 1441 & 1441 & 925 & 1441 \\
\hline$R^{2}$ & 0.36 & 0.32 & 0.36 & 0.33 & 0.35 & 0.34 \\
\hline \multicolumn{7}{|c|}{ Environmental outcomes } \\
\hline & $(1)$ & $(2)$ & $(3)$ & (4) & $(5)$ & $(6)$ \\
\hline & $\begin{array}{l}\text { Harm to } \\
\text { environment }\end{array}$ & $\begin{array}{l}\text { Harm to } \\
\text { environment }\end{array}$ & $\begin{array}{l}\text { Harm to } \\
\text { environment }\end{array}$ & $\begin{array}{l}\text { How much } \\
\text { harm }\end{array}$ & $\begin{array}{l}\text { How much } \\
\text { harm }\end{array}$ & $\begin{array}{l}\text { How much } \\
\text { harm }\end{array}$ \\
\hline Clean meat & $\begin{array}{l}-0.025 \\
(0.05)\end{array}$ & & & $\begin{array}{l}-0.000 \\
(0.06)\end{array}$ & & \\
\hline $\begin{array}{l}\text { Vegetarian } \\
\text { substitute }\end{array}$ & $\begin{array}{r}-0.030 \\
(0.05)\end{array}$ & & & $\begin{array}{l}-0.061 \\
(0.05)\end{array}$ & & \\
\hline Positivity index & & $\begin{array}{c}0.045^{* * *} \\
(0.01)\end{array}$ & & & $\begin{array}{c}0.057^{* * *} \\
(0.01)\end{array}$ & \\
\hline Easiness index & & & $\begin{array}{c}0.051^{* * *} \\
(0.01)\end{array}$ & & & $\begin{array}{c}0.064^{* * *} \\
(0.01)\end{array}$ \\
\hline Baseline value & $\begin{array}{c}-0.406^{* * *} \\
(0.02)\end{array}$ & $\begin{array}{c}-0.462^{* * *} \\
(0.03)\end{array}$ & $\begin{array}{c}-0.450^{* * *} \\
(0.03)\end{array}$ & $\begin{array}{c}-0.284^{* * *} \\
(0.02)\end{array}$ & $\begin{array}{c}-0.343^{* * *} \\
(0.03)\end{array}$ & $\begin{array}{c}-0.346^{* * *} \\
(0.02)\end{array}$ \\
\hline $\begin{array}{l}\text { Baseline meat } \\
\text { consumption }\end{array}$ & $\begin{array}{l}0.002 \\
(0.00)\end{array}$ & $\begin{array}{l}0.002 \\
(0.00)\end{array}$ & $\begin{array}{l}0.003 \\
(0.00)\end{array}$ & $\begin{array}{r}-0.002 \\
(0.00)\end{array}$ & $\begin{array}{r}-0.002 \\
(0.00)\end{array}$ & $\begin{array}{r}-0.001 \\
(0.00)\end{array}$ \\
\hline Constant & $\begin{array}{c}1.833^{* * *} \\
(0.11)\end{array}$ & $\begin{array}{c}1.512^{* * *} \\
(0.13)\end{array}$ & $\begin{array}{c}1.621^{* * * *} \\
(0.10)\end{array}$ & $\begin{array}{c}1.437^{* * *} \\
(0.08)\end{array}$ & $\begin{array}{c}0.953^{* * *} \\
(0.10)\end{array}$ & $\begin{array}{c}1.149^{* * *} \\
(0.07)\end{array}$ \\
\hline Observations & 1441 & 925 & 1441 & 1441 & 925 & 1441 \\
\hline$R^{2}$ & 0.23 & 0.27 & 0.26 & 0.13 & 0.18 & 0.18 \\
\hline
\end{tabular}


Table A2: Regression of Change in Beliefs on Messaging Treatments

\begin{tabular}{|c|c|c|c|c|}
\hline & \multicolumn{2}{|c|}{ Animal-related outcomes } & \multicolumn{2}{|c|}{ Environmental outcomes } \\
\hline & & $(2)$ & $(3)$ & $(4)$ \\
\hline & $\begin{array}{c}\text { Belief } \\
\text { about harm }\end{array}$ & $\begin{array}{c}\text { Importance } \\
\text { of harm }\end{array}$ & $\begin{array}{c}\text { Belief } \\
\text { about harm }\end{array}$ & $\begin{array}{l}\text { Importance } \\
\text { of harm }\end{array}$ \\
\hline \multirow[t]{2}{*}{ Health message } & -0.021 & -0.019 & 0.026 & -0.001 \\
\hline & $(0.07)$ & $(0.06)$ & $(0.09)$ & $(0.06)$ \\
\hline \multirow{2}{*}{$\begin{array}{l}\text { Environmental } \\
\text { message }\end{array}$} & -0.049 & 0.006 & $0.305^{* * *}$ & $0.108^{*}$ \\
\hline & $(0.08)$ & $(0.06)$ & $(0.09)$ & $(0.06)$ \\
\hline \multirow[t]{2}{*}{ Baseline value } & $-0.442^{* * *}$ & $-0.332^{* * *}$ & $-0.271^{* * *}$ & $-0.240 * * *$ \\
\hline & $(0.02)$ & $(0.02)$ & $(0.02)$ & $(0.02)$ \\
\hline \multirow{4}{*}{$\begin{array}{l}\text { Baseline meat } \\
\text { consumption } \\
\text { Constant }\end{array}$} & $-0.006^{* *}$ & -0.002 & 0.002 & $-0.004^{* *}$ \\
\hline & $(0.00)$ & $(0.00)$ & $(0.00)$ & $(0.00)$ \\
\hline & $4.514^{* * *}$ & $1.816^{* * *}$ & $2.564^{* * *}$ & $1.334^{* * *}$ \\
\hline & $(0.21)$ & $(0.08)$ & $(0.17)$ & $(0.08)$ \\
\hline \multirow{2}{*}{$\begin{array}{l}\text { Observations } \\
R^{2}\end{array}$} & 1441 & 1441 & 1441 & 1441 \\
\hline & 0.31 & 0.17 & 0.13 & 0.09 \\
\hline
\end{tabular}

Table A3: Regression of Change in Beliefs on Treatments

\begin{tabular}{lcccc}
\hline & $\begin{array}{c}\text { Animal-related outcomes } \\
(1) \\
\text { Belief } \\
\text { about harm }\end{array}$ & $\begin{array}{c}(2) \\
\text { Importance } \\
\text { of harm }\end{array}$ & $\begin{array}{c}\text { Environmental outcomes } \\
(3) \\
\text { Belief } \\
\text { about harm }\end{array}$ & $\begin{array}{c}(4) \\
\text { Importance } \\
\text { of harm }\end{array}$ \\
\hline Ethical framing & 0.005 & 0.025 & -0.057 & $-0.086^{* *}$ \\
& $(0.05)$ & $(0.04)$ & $(0.06)$ & $(0.04)$ \\
Process framing & -0.002 & -0.013 & 0.079 & -0.004 \\
& $(0.05)$ & $(0.04)$ & $(0.07)$ & $(0.04)$ \\
Clean meat & -0.086 & -0.012 & -0.031 & -0.068 \\
& $(0.07)$ & $(0.06)$ & $(0.09)$ & $(0.06)$ \\
Vegetarian & $-0.877^{* * *}$ & 0.051 & $-0.562^{* * *}$ & -0.059 \\
substitute & $(0.09)$ & $(0.07)$ & $(0.10)$ & $(0.07)$ \\
Baseline value & $-0.244^{* * *}$ & $-0.323^{* * *}$ & $-0.177^{* * *}$ & $-0.235^{* * *}$ \\
& $(0.01)$ & $(0.01)$ & $(0.01)$ & $(0.01)$ \\
Baseline meat & 0.001 & 0.000 & 0.002 & 0.002 \\
consumption & $(0.00)$ & $(0.00)$ & $(0.00)$ & $(0.00)$ \\
Constant & $3.001^{* * *}$ & $1.779^{* * *}$ & $1.994^{* * *}$ & $1.387^{* * *}$ \\
& $(0.13)$ & $(0.07)$ & $(0.11)$ & $(0.07)$ \\
\hline Observations & 3488 & 3233 & 3488 & 3232 \\
$R^{2}$ & 0.17 & 0.17 & 0.08 & 0.09 \\
\hline
\end{tabular}

